\title{
Financialization and Deindustrialization in the Southern European Periphery
}

\author{
By Francesca Gambarotto ${ }^{*}$,Marco Rangone ${ }^{\dagger}$, Stefano Solari ${ }^{*}$
}

Historically, Southern European countries have shared a 'semi-peripheral' model of capitalism which has been characterized by fundamental fragilities in the production system. The financialization induced by the EMU has rendered these economies more fragile and unstable. Liberalization and market reform policies have taken southern economies onto the path of a credit-based and passively-extroverted financialized economy that trap them into a low-cost-of-wages search of competitiveness. However, the lack of autonomy in macroeconomic policies has weakened Southern opportunity to react to the financial crisis. The 'internal devaluation' policies that followed have caused a deep and thorough process of de-industrialization. This has sped-up the centralization of the European economy that has its centre in a narrow space within Paris, Amsterdam, Berlin and Frankfurt.

Keywords: Southern Europe, Financialization, Deindustrialisation, Peripheralization.

\section{Introduction: The Crisis of Latecomers}

Southern Europe has been especially hard hit by de-industrialization since the 2008 crisis. That has been seen as the effect of an asymmetric shock, which the European Union was badly structured to absorb (Jäger and Springler 2015, Celi et al. 2017). The result is stagnating demand, difficulties with banks' credits, high unemployment rates and precarious employment. The point discussed here, is that as the European economy, particularly the Economic and Monetary Union (EMU), is increasingly interconnected, this asymmetric impact of the crisis is to be seen as a regional problem and not as international.

We actually find different interpretations of this phenomenon. Post-Keynesian and institutionalist scholars relate it to deflationary policies and to the asymmetric form taken by EMU (Stockhammer 2011, Becker 2013). However, even Jonathan Hopkin (2015) points to mistaken policies and Peter Hall (2014) sees this phenomenon as a consequence of the macroeconomic shock due to the post-2008 financial crisis austerity policies. Here, we argue that there is a deeper causal effect related to the core-periphery dynamics ignited by the European unification process, which has in turn simply been accelerated by the financial crisis and deflationary policies.

This kind of argument has been highlighted in different ways by both Reinert (2013) and Magone et al (2016) as well as in a growing literature on peripheralization concerning the European regions. Peripheralization is defined as

\footnotetext{
*Associate Professor, University of Padua, Italy.

${ }^{\dagger}$ Assistant Professor, University of Padua, Italy.

*Associate Professor, University of Padua, Italy.
} 
"the process of becoming disconnected from and dependent on the centre' (Fischer-Tahir and Naumann 2013: 9). From this perspective, we are witnessing an ongoing restructuring of Europe's economic geography, which is redefining its centres and its peripheries. Continental centres, principally Paris, Frankfurt, Berlin and Amsterdam are gaining importance, while centres of peripheral regions such as Milan, Lisbon and Athens are losing their capacity to attract economic activity. This transformation is propelled by policy weakness and financialization, due to the prevailing logic of increasing capital mobility (van der Zwan 2014). Unfortunately, this dynamic is pushing Mediterranean countries towards the periphery of Europe and back into the semi-periphery of the 'developed world' economic system, joining there the South-East periphery (Epstein 2014).

We take the concept of 'semi-periphery' from Wallerstein's (1979) argument that the world economy is structured according to centre-periphery relationships. Such relationships directly connect production and location processes along international commodity chains. Core activities are those that command a large share of total surplus, whilst peripheral activities only command a minor share. Furthermore, due to increasing returns, core activities tend to cluster in regions that are accordingly called 'central regions'. Institutional and political reasons as well as locational advantages like positive externalities and concentrated demand are responsible for clustering. On the other hand, semi-peripheral regions show a mixed picture and their success crucially depends on the support of well-conceived and well-developed institutions.

In Wallerstein's view, the development of a region is the result of a process of structural change, from an economic system characterised by low value-added activities to one with a high share of strongly connected high value-added activities. This change tends to affect wage levels positively. However, a positive development path is strictly related to the coherence of institutions, particularly those that facilitate the production and redistribution of value in the economy. Losing the coherence of economic institutions reduces their support role relative to global competition and may cause a process of peripheralization.

What distinguishes the Southern European countries (Spain, Italy, Portugal and Greece) is that industrialisation has occurred relatively recently compared to Continental European capitalism. Their economies have been characterised by a process of 'late development' (Fuà 1980) that resulted in an idiosyncratic model of capitalism that has attracted little attention in the contemporary literature compared to coordinated or market-based liberal capitalism (Hall and Soskice 2001, Amable 2003, Gambarotto and Solari 2015, Molina and Rhodes 2007, Nölke 2016). In this case, 'late development' has created a degree of inconsistency between the production system and the requisite institutions, which has been typically compensated in these countries by state intervention. Governments have played an important role in addressing development requirements, attempting to correct the inconsistencies between the production system and national institutions, while inadvertently enhancing them creating dependency (Molina and Rhodes 2007). They did so through direct intervention, regulation and the control of private economic activity. These countries also developed generous pension systems to help curb the high social costs of structural transformation (becoming 
pensions-heavy welfare states) and diverged from the continental economies by also creating a universal health system, but investing little in unemployment support or vocational training (Ferrera and Rhodes 2000).

As for economic activity, Southern 'late development' countries saw the emergence of an industrial structure based on traditional sectors, with a dualism of economic organisation between large corporations, often state-owned, and certain dynamic clusters of small firms. The labour market was characterised by a fragmented corporate structure, dualism (between core and 'outsider' workers) in labour contracts and growing levels of precarious employment. The financial system was mainly based on bank credit, while stock exchanges have long remained underdeveloped and are still characterised in large part by speculative investment (see also Baumeister and Sala 2015).

'Late development' tends ultimately to evolve into 'semi-peripherality' (Arrighi and Drangel 1986). We believe that this has indeed been the case for Southern Europe. Unsurprisingly, the strategic behaviour of governments is critical in driving the evolutionary process of a latecomer country, as it is obliged to play a greater role than in continental European countries in overcoming lags and counterbalancing fragility - an important problem that is now confronting EU policies (Reinert 2013).

Historically, while some latecomers such as Japan, and a number of other Asian economies (Taiwan, South Korea, Singapore) have succeeded in upgrading their economies over time, others - including the Southern European countries have succeeded only partially, and have constantly been at risk of economic downgrading. The Southern European economies increased their levels of industrial production until the 1990s. They also benefitted from the decentralisation of production from Continental Europe. That induced a degree of industrial specialisation in ancillary production, medium-low technologies and consumer products. The low level of capitalisation of industry meant a high return on capital. But at the same time, it did not incentivise measures to improve low labour productivity. In spite of their direct roles, governments have been unable to alter this trajectory, creating instead a situation of dependency - on external aid (e.g. the European Structural Funds) as well as on credit (Lains 2019). The difficulty in building real competitive advantage for business led to policies - such as frequent currency depreciations - that actually maintained the low wage-low, productivity link, or bolstered profitability only via the weak enforcement of rules (Rangone and Solari 2012).

Regardless of state intervention, the pattern of growth in the Southern European economies was largely 'spontaneous' rather than planned or directed, with simple (non-technology driven) agglomeration effects in some urban areas, little labour mobility and an absence of regional convergence. In general, neither research and development (R\&D), nor the intensity of human resources, especially in the important science and technology sectors, have ever been a central concern of governments, and are still relatively scarce. Gambarotto and Solari (2009: 3435) note that the Mediterranean model of capitalism displays a highly unequal form of regional growth and an uneven distribution of the population. Per capita GDP and employability are spatially concentrated and low on average. R\&D 
investments are also low and barely differentiated geographically. Household income, employment opportunities and long-term unemployment differ greatly among regions even after redistribution via welfare state institutions.

These countries had to reform their institutions, sometimes forcibly, to adapt to the process of European integration. Their old institutions were ill-matched with the new principles underpinning the European common market and, eventually, the EMU. Nonetheless, the newer and reformed institutions that these countries developed also appear to be unfit for underpinning a stable process of growth and the achievement of full employment. We attribute this failure also to the process of financialisation that has disembedded production activities. EMU has played an important role in this respect, creating strong pressures for the reform of economic institutions in a more open and market-oriented direction favourable to the mobility of European and international finance (Barradas et al. 2018). Globalisation has further lowered the fences protecting the local environment from far-East industries, resulting in serious problems of competitiveness, due to the weak forms of industrial specialization in the European south. Even if EMU has been of some benefit to the Southern European countries through lower interest rates, a looser monetary environment also led in the period between 2000 and 2008 to an excessive increase in both private and public debt and subsequently to financial instability. Deindustrialisation and high unemployment is the final chapter of this story, leading these countries into difficulties similar to the Central and Eastern European countries and placing them directly into competition with them (Epstein 2014).

\section{Monetary Union and Financialization}

EMU has created a favourable environment for the process of financialization (Stockhammer 2008), defined as an increased role for financial activities in the economy and financial deepening (the ratio of debt to GDP). Financialization acquired a specific character in the Southern European economies, one in which neither a marked expansion of financial institutions nor an increase in the financial assets in companies' balance sheets has occurred (Orsi and Solari 2010). Predictably, financialisation in Southern Europe has taken a peripheral path.

There are many ways to disembed capital, depending on the different patterns of accumulation prevailing. Becker et al. (2010) and Becker and Jäger (2012) have identified a set of characteristics that help define an accumulation regime in the periphery. The first distinction is between productive and financialized accumulation, which accounts well for the substitution of real investment with financial assets to maintain capital profitability. Financialized accumulation can be further divided into accumulation based on different types of securities and accumulation based on interest-bearing credit. The latter is typical of peripheral financialization. The second distinction identifies extensive versus intensive accumulation regimes. The former, typical of peripheral regimes, is based on an increasing exploitation of production factors, while the latter achieves growth via productivity increases. The third characterization is between extroverted and 
introverted accumulation. The former is based on enlarging markets, while the latter is based on an expansion of internal demand. An extroverted accumulation regime can also result in a passive form of import-orientation. In the last twenty years, the accumulation regime of Southern Europe's economies has become financialized through an expansion of public and private credit, involving a more extensive exploitation of production factors alongside a passively-extroverted trading system (Gambarotto and Solari 2015).

The process whereby Southern Europe's economies embraced this form of financialization can be summarized as follows.

Firstly, the liquidity and mobility of capital was increased thanks to the euro. These countries attracted capital investment from the continental European economies in the early 2000s, seeking higher investment returns in the periphery. Inflation, which at that time was from one to three per cent higher in the South than in continental Europe, also provided an additional source of higher returns for investors from the same currency area, notably France and Germany. The real estate sector was the principal final target of financial investment.

Secondly, this flow of capital was facilitated by a shift in the business strategy of the southern banking systems, whose banks - also seeking higher returns limited credit for the expansion of industrial production, lending more eagerly to building societies and consumers (including mortgages). That massive investment shift inflated a real estate and construction bubble (of dramatic proportions in Spain) that also inflated the collateral used for standard credit. Moreover, the bubble contributed to an increase in aggregate demand which sucked in higher imports, by simply creating a higher capacity for import absorption in a context of weakening local production.

Thirdly, many entrepreneurs facing globalization shifted their investments into public utilities (e.g. Benetton family controls Italian toll road operator "Autostrade") or to financial companies (the Pesenti family sold its cement industry to Heidelberg Cement and focused its capital in investment funds as Clessidra) rather than strengthening their industries through investment. Many sold their businesses to foreign enterprises (e.g. the Greek Maris Polymers was acquired by the French Saint-Gobain), while others relocated production (e.g. Greek SMEs to Bulgaria to reduce operational costs). This tendency weakened Southern 'family capitalism' and helped concentrate the control of industry in the hands of core EU financial centres and Continental European companies.

We argue that these effects of financial globalization have increased the fragilities of Southern capitalism depicted in the previous section, thereby weakening the structure of industry and initiating a process of de-industrialization that in the present context is difficult to reverse. Moreover, European stability policies in 2011-2012 magnified these tendencies. Those policies were primarily oriented towards cutting public deficits, but they were not particularly effective in achieving this objective because of their unexpectedly high impact in reducing GDP and, consequently, government tax revenue. These policies have been more effective in regard to 'internal devaluation', which was conceived as a substitute for actual currency devaluation to moderate the growth in these countries' international debt and excessive import levels. Therefore, internal demand 
(absorption) had to be cut by means of selective measures. This involved reducing public expenditure (e.g. pensions) as well as wage cuts and a flexibilization of the labor market, which increased the proportion of precarious (i.e. largely unprotected) employment and drastically reduced the level of consumption. These policies led to a form of 'regional repression' of demand and certainly did not assist in industrial restructuring and consolidation. Finally, falling consumer expenditure, the specific form of industrial specialization and structure found in the Southern countries, as well as the absence of a coordinated European industrial policy, made national or regional responses to this process difficult to implement or even conceive. Therefore, the joint effects of market integration, the loss of control on monetary policy and globalization had important regional consequences for industry in the South.

\section{Fragility and Inappropriate Policies}

Passive and extroverted financialization has made Southern European economies more fragile and more vulnerable to both Central and Eastern European competition and macroeconomic shocks. At the end of the 2000s, the European Central Bank's restrictive monetary policy led to a euro/dollar exchange rate of around \$1.30-1.40. This helped boost imports while placing pressure on exportoriented industries. From 2011, austerity policies have done little to help a periphery that has experienced a financialization-induced process of 'boom and bust'. These deflationary policies have had multiple effects.

- Because of euro appreciation, imports from non-euro areas became cheaper, and had an intense impact on Southern European manufacturing which is more directly exposed to low-cost, labour-intensive production than that of the economies of the North. Many firms relocated production to reduce costs and increase competiveness on international markets but that hardly hit the local supply chains made up of small firms.

- Due to badly-conceived financial stability reforms (at least with a bad timing), commercial banks had to increase their capital-assets ratio and did it by cutting lending, thereby inducing a serious credit crunch in these economies where production is mostly financed by credit.

- Banks became even more reluctant to finance industry exposed to Asian or European competitors or facing difficulties with domestic demand ${ }^{1}$. They cut all kind of lending, but particularly short-term lending which is vital for the solvency of small firms. Even when the BCE increased the money supply through 'quantitative easing', little by way of finance flowed from banks to small companies. At the same time, banks that were obliged to reduce lending, began to suffer from exploding non-performing-loans (NPLs) caused by the same credit crunch. First of all, reduced lending

\footnotetext{
${ }^{1}$ Banks had to increase their capital-assets ratio from an average of 4-5 per cent to $12-13$ per cent. Many banks increased their risk capital, but the required capital ratios of Basel II and III and the criteria imposed by EBA and later ECB were difficult to meet and therefore they also cut lending.
} 
interrupted the positive feed-back mechanism by which banks financed both producers and consumers via mortgages. That halted the real estate bubble causing prices fall. This reduced the capacity of building societies to repay loans, and the decreasing prices of unsold buildings further reduced the value of banks' guarantees. As regards industry, as small and medium-sized firms depend a great deal on short-term credit for funding, when banks reduced credit and requested that companies pay back former loans (at a time of narrowing margins), the number of companies falling into insolvency increased. Consequently, in a credit-based system of financing production, a credit crunch has insolvency effects that then induce a feed-back effect on the banks themselves.

- Instead of a patient policy of a long and prudent recovery from NPLs which had been used in the past to deal with banks' experiencing difficulties with bad loans - the monetary and banking authorities demanded an instant devaluation and sell-off of NPLs, which caused a steep fall in NPL prices, allowing huge losses to emerge on the balance sheets of banks. In the case of Italian banks, bad credits that normally had a recovery rate of 70-80 per cent in some cases had to be rapidly sold at prices around 13-17 per cent. ${ }^{2}$ That has led to the failure of many banks, large losses in the assets of middle-class families, and severe problems for production systems obliged to rapidly repay credits. On the other hand, the financial firms that purchased NPLs and patiently recovered credits are presently making huge profits.

- 'Internal devaluation' called for wage cuts, thereby decreasing aggregate demand. Households consequently reduced consumption while uncertainty further induced a contraction in consumer demand. That severely impacted local production systems.

- Aggregate demand also decreased because public expenditure was reduced while taxation was increased. Before 2008 the Southern European countries' stock of public debt was contained - even if deficits occurred because a higher growth of GDP allowed the ratio of debt to GDP to remain under control. The recessionary impact of measures undertaken to deal with the financial crisis contributed to the expansion of both deficits and debt (see also Koutsoukis and Roukanas 2016).

These feed-backs had different intensities and specificities in each Southern country or region. For all, the deflationary shock had a serious impact on the industrial economy, simply because growing internal demand was a primary condition of the competitive equilibrium of many traditional sectors (food, cloths, furniture etc.). In fact, growing demand ensures productivity growth thanks to a better exploitation of production capacity without the need for major restructuring or technological change (the second of Kaldor's three laws of growth). The result has been a rapid process of de-industrialization. Services and non-traded goods

\footnotetext{
${ }^{2}$ The reason is twofold: firstly, a market for NPLs did not exist, secondly, banks were not ready in terms both of a complete documentation on these credits to securitize the demand of administrative personnel able to work on this process.
} 
were also affected by internal devaluation, as fixed costs were reduced and the quality of services decreased accordingly. Many economists welcomed these policies in the hope that they would induce a concentration of production in larger units and a recapitalisation of companies. In fact, the crisis of smaller firms is inducing both a selection in favour of, and a process of aggregation into, larger units of production. However, this restructuring process is slow, costly and insufficient to counter-balance the huge economic and social costs of austerity. In other words, 'peripheralization', according to Arrighi and Piselli (1987: 687) is a process whereby local actors are progressively deprived of the benefits of participating in the global division of labour, to the advantage of other actors or regions. As a consequence, countries that had already entered the perimeter of the core - Italy in the 1970s and Greece, Spain and Portugal in the 1990s - tend to be limited in their ability to remain in this position. Portugal and Greece are in an even worse situation than the others, having partially failed to strengthen and stabilize their production structures in the pre-crisis period.

On the one hand, these economies experienced great difficulty in following the growth pattern of continental economies, such as Germany and France, whose forms of production specialisation and the scale of their firms and service sectors are larger and stronger, incorporating higher technologies. This has been the case particularly of Italy, Portugal, and Greece once the introduction of the single currency prevented them from compensating for higher average inflation rates than in the European core.

According to Fischer-Tahir and Naumann (2013: 9) peripheries are "the outcome of complex processes of change in the economy, demography, political decision-making and socio-cultural norms and values". Certainly, the southern debt crisis of 2011 has reduced the political strength of Southern countries in shaping European policies, especially Italy. These countries have therefore lost credibility and have not been able to propose coherent stabilization policies compatible with the structure of their economies. This has contributed to the political marginalization of their economies.

\section{Deindustrialization in the South of Europe}

So far, we have seen that Southern European economies faced many difficulties in EMU due to structural asymmetries. At the beginning of the fixedexchange rate period (euro adoption), they suffered from inflation differentials with Continental Europe which increased their labour costs in real terms. Then the appreciation of the euro caused their imports to boom while slowing down exports. The 2008 crisis and the consequent fall in demand led to a huge loss of employment, firms and production. Finally, debt-deflationary policies caused financial problems that induced a further fall in production and employment.

In Table 1 we have distinguished the two steps of the crisis: 2008-2012 and 2012-2016. We can clearly see the differential impact of the 2008-2012 crisis on industrial employment at the centre (Germany and France) and in periphery. The group of Southern de-industrialising countries clearly appears as suffering both a 
loss of firms and jobs, though more jobs than firms in Spain, and more firms than jobs in Greece. If in the period before 2008 Southern European industry faced difficulties in keeping up with industrial growth in the rest of the Euro area - with the partial exception of Spain - after 2008 Southern Europe experienced a veritable collapse.

Table 1. Deindustrialization: Employment and Firms, 2008-2012 and 2012-2016

\begin{tabular}{|c|c|c|c|c|}
\hline & \multicolumn{2}{|c|}{ Enterprises - Number } & \multicolumn{2}{c|}{$\begin{array}{c}\text { Employees in Full Time } \\
\text { Equivalent Units - Number }\end{array}$} \\
\hline & $2008-2012$ & $2012-2018$ & $2008-2012$ & $2012-2018$ \\
\hline Germany & $4.2 \%$ & $-0.9 \%$ & $0.1 \%$ & $2.3 \%$ \\
\hline France & $2.9 \%$ & $-0.8 \%$ & $-5.8 \%$ & $-4.5 \%$ \\
\hline Greece & $-24.0 \%$ & $-4.2 \%$ & $-16.1 \%$ & $-6.4 \%$ \\
\hline Spain & $-15.2 \%$ & $-5.1 \%$ & $-26.2 \%$ & $3.5 \%$ \\
\hline Italy & $-9.2 \%$ & $-7.1 \%$ & $-13.3 \%$ & $-6.2 \%$ \\
\hline Portugal & $-17.1 \%$ & $-0.8 \%$ & $-15.7 \%$ & $6.5 \%$ \\
\hline
\end{tabular}

Source: Eurostat, NACE R2, INDIC SB.

Figure 1. Manufacturing Value Added at Constant Prices

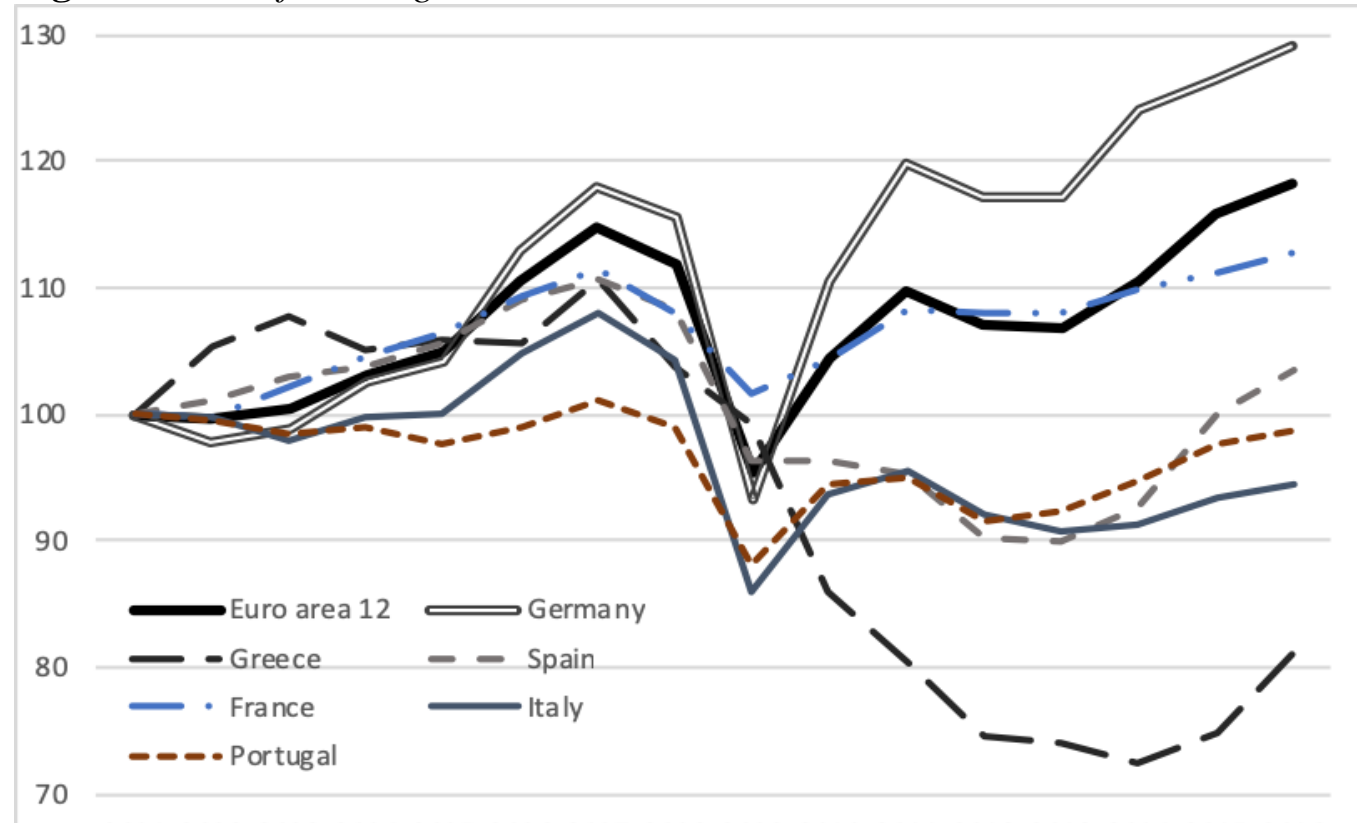

2001200220032004200520062007200820092010201120122013201420152016

Source: Eurostat, NACE R2, NA ITEM.

The second step of the crisis, 2012-2016, characterized by internal devaluation and debt deflation has particularly hit Greece and Italy, while Spain and Portugal have seen a certain recovery of unemployment (which remains at unacceptable levels). France also begins to suffer from the deflationary environment. The weaknesses of Southern industry are evident from data on value added in manufacturing (Figure 1 and Table 2). 
Table 2. Manufacturing Value Added as a Percentage of GDP

\begin{tabular}{|l|c|c|c|c|}
\hline & $\mathbf{2 0 0 1}$ & $\mathbf{2 0 0 7}$ & $\mathbf{2 0 1 2}$ & $\mathbf{2 0 1 6}$ \\
\hline Euro area 12 & 17.1 & 15.8 & 14.5 & 15.3 \\
\hline Germany & 20.5 & 21.1 & 20.4 & 20.6 \\
\hline France & 13.7 & 11.4 & 10.2 & 10.2 \\
\hline Greece & 9.9 & 8.5 & 8.0 & 8.6 \\
\hline Spain & 15.8 & 13.5 & 12.1 & 12.9 \\
\hline Italy & 17.1 & 15.9 & 13.8 & 14.6 \\
\hline Portugal & 14.7 & 12.2 & 11.4 & 12.1 \\
\hline
\end{tabular}

Source: Eurostat Gross value added and income by A*10 industry breakdowns [nama_10_a10]

The difficulties of the Southern economies is evident in Figure 2, which records the slowing down of GDP per hour worked that began at the end of the 1990s in Italy and Spain and just before the crisis in Greece. Portugal experiences no such decrease, but diverges nonetheless from the general European trajectory. Therefore, exposed to higher competition, people in Southern Europe work an increasing number of hours but produce less and less. The flexibilization of the labor market adopted to cope with the euro is probably no stranger to this tendency.

Figure 2. Relative GDP per Hour Worked

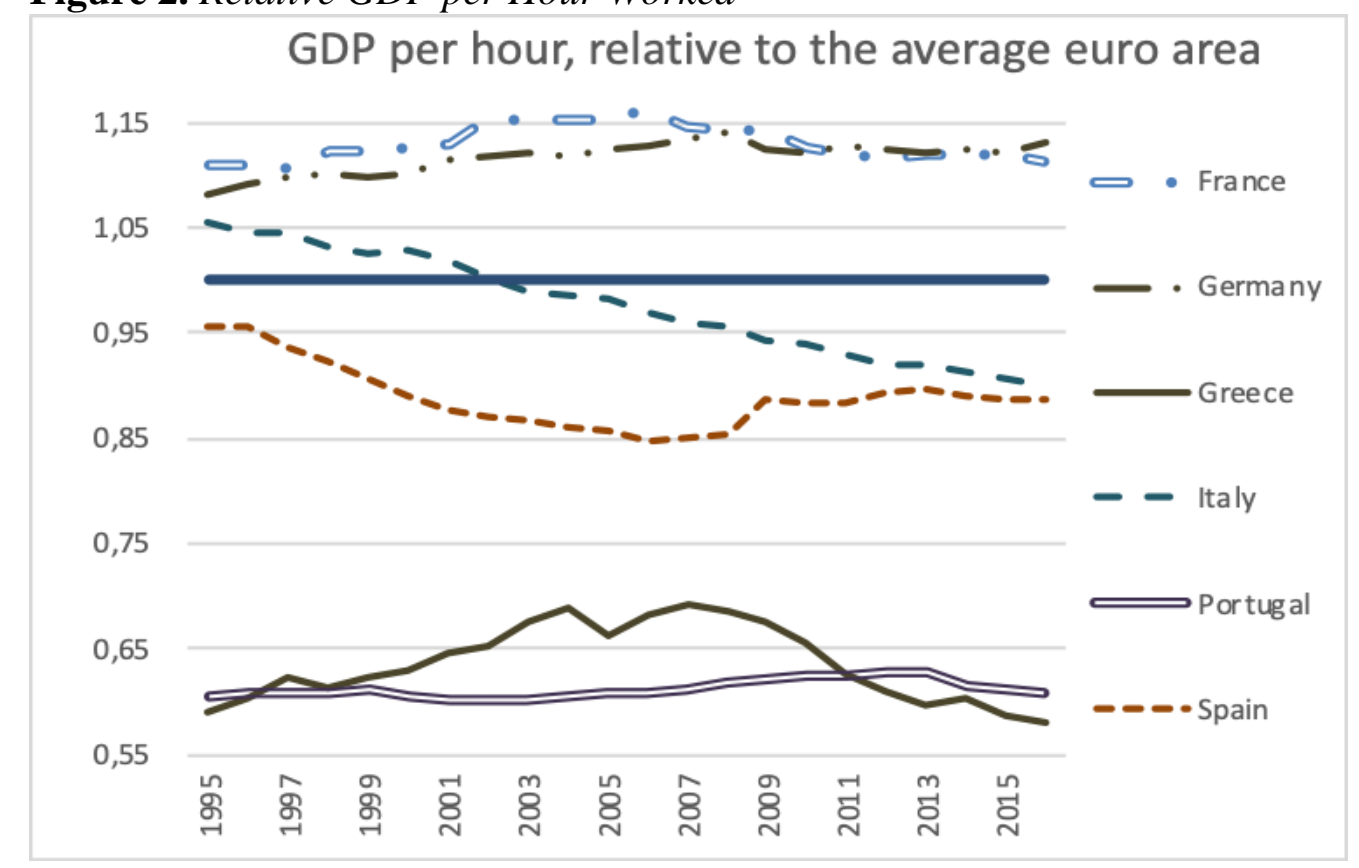

Source: OECD, Dataset: Productivity.

However, it would be wrong to imagine that Southern European industry is not responding to the crisis and to deflationary policies. A part of the production system is well integrated into the European economy. Exports to the European core countries, in fact, responded to internal devaluation and increased rapidly after 2008. The composition of exports also changed considerably. The export of 
low-tech products fell and the share of high-technology products grew substantially, representing an important structural change in the Southern European economies during the euro period. But this restructuring is insufficient to compensate for absolute losses as the ratio between the gains of high tech exports and losses from declining low-tech exports is about one fifth.

These figures also show how Southern Europe's weak level of industrial specialization has been more exposed to international competition and been difficult to restructure. European adhesion to WTO agreements, such as the MultiFibre Agreement (MFA) ${ }^{3}$, which, although leaving a lot of time - almost 30 years - for leading firms to adjust by relocating production and reinforcing their channels of distribution, left a huge number of small firms operating in the intermediate phases of production exposed to competition from low-cost labor countries. For the majority of these firms operating in mature sectors, production specialization resulted in a cul-de-sac in terms of opportunities for upgrading. This situation opened huge opportunities for leading fashion firms, disembedding themselves from local networks of production, but imposed high social costs on various parts of the South tied to the fall in the number of firms (see Table 1). These trajectories in the restructuring process led to an increased differentiation of income and impoverished certain sections of the middle class. Due to public externalities, this problem should have been dealt with by public policies - at different levels - as a regional problem affecting a large area of Europe and not simply as a private problem of adaptation to the market. Nonetheless, Southern European countries, as well as their institutional actors and the firms concerned have been unable to respond by developing an industrial policy appropriate to the tasks at hand.

\section{The Evidence for European Industrial Polarization}

Between 2009 and 2012, the industrial specialization of the countries covered here did not change much as a result of the crisis. Greece and Portugal have been unable to develop significant industrial activities beyond textiles, apparel and metal products. Spain and Italy have more diversified industrial structures, while the French and especially German industrial structures are more specialized in machinery, transport equipment and chemistry. The loss of competitiveness in the textiles and apparel sectors in all countries, likely due to the difficulties in adjusting to WTO agreements like the MFA, had a greater impact on South Europe, particularly Greece, Portugal and Italy (Simonazzi et al. 2013). Southern countries have been particularly hit in the textile and apparel sectors as well as in the sectors that benefit from housing investment (non-metallic minerals, metal constructions, furniture). The southern economies were specialized in household consumption goods. This industry was partly crowded out by both Central and Eastern European and Asian production and partly suffered from the reduction in

\footnotetext{
${ }^{3}$ The Multi-Fibre Arrangement (MFA) governed world trade in textiles and garments from 1974 to 2004, imposing quotas on the exports of developing countries to developed countries. It expired on 1 January 2005.
} 
consumer demand and, above all, from the reduction of prices. The reduction of prices is the consequence of two main developments: increased competition from foreign suppliers, and a composition effect caused by a reduction in related demand due to the weakening of prosperity among the Southern middle classes and an increase in demand for low quality/price goods.

In some sectors - automobile and transport equipment, rubber and plastic, chemicals, and electric equipment industries the distribution of employment has moved from the periphery to the centre (see Table 6 below). The food industry is characterized by a particularly notable reduction of employment in the Iberian Peninsula, while the proportion of jobs has increased in Germany and France: this is an interesting case of the tendency towards concentration. The fact that after the crisis management and clerical employment declines in the South and increases considerably in the North is a clear sign of the centralization of management activities in the European core (see Table 5 below). The significant loss of skilled jobs is equally worrying for the South.

Table 3. Relative Trade Balances, 2009-13 (in percentages)

\begin{tabular}{|l|c|c|c|c|c|c|c|c|c|c|}
\hline $\begin{array}{l}\text { Relative } \\
\text { trade balance }\end{array}$ & $\mathbf{2 0 0 9}$ & $\mathbf{2 0 1 3}$ & $\mathbf{2 0 0 9}$ & $\mathbf{2 0 1 3}$ & $\mathbf{2 0 0 9}$ & $\mathbf{2 0 1 3}$ & $\mathbf{2 0 0 9}$ & $\mathbf{2 0 1 3}$ & $\mathbf{2 0 0 9}$ & $\mathbf{2 0 1 3}$ \\
\hline $\begin{array}{l}\text { (exp-imp)/ } \\
\text { (exp+imp) }\end{array}$ & Germany & Germany & Greece & Greece & Italy & Italy & Portugal & Portugal & Spain & Spain \\
\hline Fresh food & -28 & -26 & -20 & -10 & -39 & 38 & -58 & -49 & 9 & 15 \\
\hline $\begin{array}{l}\text { Processed } \\
\text { food }\end{array}$ & 7 & 10 & -26 & -7 & 3 & 9 & -9 & -5 & -2 & 7 \\
\hline Wood products & 14 & 10 & -74 & -61 & -16 & 12 & 25 & 34 & -6 & 4 \\
\hline Textiles & 3 & 2 & -23 & -18 & 25 & 22 & 3 & 3 & -3 & 1 \\
\hline Chemicals & 16 & 17 & -57 & -43 & -12 & -6 & -37 & -22 & -15 & -5 \\
\hline $\begin{array}{l}\text { Leather } \\
\text { products }\end{array}$ & -27 & -27 & -75 & -63 & 29 & 34 & 23 & 23 & -5 & -2 \\
\hline $\begin{array}{l}\text { Basic } \\
\text { manufactures }\end{array}$ & 15 & 9 & -17 & 6 & 18 & 17 & -7 & 5 & 10 & 22 \\
\hline $\begin{array}{l}\text { Non-electronic } \\
\text { machinery }\end{array}$ & 36 & 36 & -66 & -41 & 46 & 50 & -31 & -5 & -11 & 8 \\
\hline $\begin{array}{l}\text { IT \& } \\
\text { Consumer } \\
\text { electronics }\end{array}$ & -20 & -21 & -77 & -63 & -52 & 47 & -38 & -27 & -60 & -64 \\
\hline $\begin{array}{l}\text { Electronic } \\
\text { components }\end{array}$ & 13 & 14 & -52 & -34 & 6 & 11 & -15 & 0 & -20 & -2 \\
\hline $\begin{array}{l}\text { Transport } \\
\text { equipment }\end{array}$ & 29 & 39 & -86 & -76 & -10 & 10 & -22 & 1 & 17 & 24 \\
\hline $\begin{array}{l}\text { Clothing } \\
\text { Miscellaneous } \\
\text { manufacturing }\end{array}$ & -29 & -31 & -43 & -28 & 11 & 20 & 13 & 20 & -26 & -13 \\
\hline Minerals & -57 & -56 & -64 & -21 & -65 & 60 & -52 & -33 & -62 & -53 \\
\hline \begin{tabular}{l} 
Source Intr| \\
\hline
\end{tabular} & 16 & -67 & -43 & 20 & 27 & -23 & -1 & -30 & -20 \\
\hline
\end{tabular}

Source: International Trade Center- http://www.intracen.org. 
Table 4. Exports per Capita, 2009-13 euro

\begin{tabular}{|c|c|c|c|c|c|c|c|c|c|c|}
\hline Per capita exports & $\mathbf{2 0 0 9}$ & $\mathbf{2 0 1 3}$ & $\mathbf{2 0 0 9}$ & $\mathbf{2 0 1 3}$ & $\mathbf{2 0 0 9}$ & $\mathbf{2 0 1 3}$ & $\mathbf{2 0 0 9}$ & $\mathbf{2 0 1 3}$ & $\mathbf{2 0 0 9}$ & $\mathbf{2 0 1 3}$ \\
\hline & Germany & Germany & Greece & Greece & Italy & Italy & Portugal & Portugal & Spain & Spain \\
\hline Fresh food & 268.5 & 362.8 & 248.4 & 288.6 & 167.9 & 206.2 & 123.7 & 211.4 & 450.8 & 590.5 \\
\hline Processed food & 561.8 & 738.9 & 246.7 & 344.2 & 406.3 & 524.6 & 350.1 & 491.5 & 360.6 & 489.6 \\
\hline Wood products & 362.4 & 401.1 & 23.8 & 31.7 & 136.5 & 165.1 & 304.9 & 469.1 & 128.9 & 160.4 \\
\hline Textiles & 147.6 & 176.8 & 54.2 & 43.0 & 195.9 & 220.7 & 144.9 & 201.7 & 78.2 & 93.6 \\
\hline Chemicals & $2,225.1$ & $2,843.2$ & 264.2 & 312.3 & 805.4 & $1,118.2$ & 380.9 & 670.1 & 721.5 & 990.1 \\
\hline Leather products & 64.3 & 93.4 & 14.1 & 17.4 & 269.7 & 395.9 & 159.3 & 246.6 & 78.9 & 101.7 \\
\hline Basic manufactures & $1,161.7$ & $1,489.2$ & 263.9 & 347.4 & 805.4 & $1,015.6$ & 427.0 & 628.7 & 521.1 & 719.4 \\
\hline $\begin{array}{c}\text { Non-electronic } \\
\text { machinery }\end{array}$ & $2,314.6$ & $2,961.5$ & 75.5 & 80.1 & $1,405.7$ & $1,708.0$ & 266.5 & 412.7 & 422.9 & 589.4 \\
\hline $\begin{array}{c}\text { IT \& Consumer } \\
\text { electronics }\end{array}$ & 421.8 & 516.0 & 35.1 & 37.1 & 97.6 & 106.5 & 146.7 & 150.7 & 80.9 & 63.4 \\
\hline $\begin{array}{c}\text { Electronic } \\
\text { components }\end{array}$ & $1,005.3$ & $1,326.7$ & 60.0 & 79.9 & 344.4 & 388.3 & 209.4 & 308.2 & 187.9 & 266.1 \\
\hline Transport equipment & $2,386.7$ & $3,544.7$ & 70.4 & 39.3 & 625.0 & 728.9 & 471.3 & 616.0 & $1,020.4$ & $1,257.1$ \\
\hline Clothing & 201.3 & 232.2 & 97.6 & 85.9 & 325.9 & 389.2 & 252.6 & 322.0 & 166.4 & 248.5 \\
\hline $\begin{array}{c}\text { Miscellaneous } \\
\text { manufacturing }\end{array}$ & $1,197.2$ & $1,513.4$ & 86.7 & 101.3 & 656.8 & 804.3 & 263.7 & 408.5 & 234.9 & 275.7 \\
\hline Minerals & 385.7 & 659.2 & 202.5 & $1,344.4$ & 271.5 & 419.4 & 275.7 & 730.2 & 269.4 & 560.7 \\
\hline
\end{tabular}

Source: http://www.intracen.org/itc/market-info-tools/trade-statistics/ 
Except for ITC and consumer electronics, clothing and minerals, the German trade balance is in surplus, while for Greece and the Iberian Peninsula, it is in deficit for nearly all sectors (Table 3). Italy has a stronger industrial base compared with the other Southern countries, but the trend is not positive. With internal devaluation, deficits tend to be reduced, but the intensity of this reduction is modest compared to the sacrifices made by these economies. This policy has been more effective in the case of Italy where a degree of diversified industrial supply still exists. This fact reveals that there is not only a clear problem of specialization for the South. The issue is rather a general weakness across all sectors.

Table 4 is even more impressive because it shows sectoral per-capita exports for 2009 and 2013. Remarkably, Germany shows higher values in all sectors. Even the German export of both fresh and processed food shows higher and faster growing values than for other countries (except Spain). No comparative advantages in the South emerge from this table. Rather, Germany seems to hold an absolute advantage in almost all sectors. The implications of absolute advantage have not yet been thoroughly investigated by economists (Camagni 2001). Nonetheless, they represent a problem in an integrated economic area as it means that no balanced, competitive equilibrium can be reached between different regions of the European economic space. Therefore, in this situation, even deflationary policies have only a short-run positive financial effect on the balance of payments, leading to little improvement in Southern industrial production.

Table 5. Percentage Change in Manufacturing Employment 2008-2014

\begin{tabular}{|l|c|c|c|c|c|c|c|}
\hline $\mathbf{2 0 0 8 - 2 0 1 4}$ & Germany & France & SOUTH & Italy & Spain & Portugal & Greece \\
\hline Total & $\mathbf{- 3 . 7}$ & $\mathbf{- 1 4 . 8}$ & $\mathbf{- 1 9 . 7}$ & $\mathbf{- 1 0 . 1}$ & $\mathbf{- 2 8 . 3}$ & $\mathbf{- 1 5 . 0}$ & $\mathbf{- 4 1 . 9}$ \\
\hline $\begin{array}{l}\text { Managers, professionals, and } \\
\text { technicians }\end{array}$ & 9.1 & 5.3 & -9.8 & -2.0 & -18.3 & 42.8 & -55.2 \\
\hline $\begin{array}{l}\text { Clerical, service and sales } \\
\text { workers }\end{array}$ & 17.4 & -23.3 & -15.2 & -12.6 & -3.6 & -34.2 & -23.0 \\
\hline $\begin{array}{l}\text { Skilled agricultural and trades } \\
\text { workers }\end{array}$ & -12.5 & -9.8 & -20.7 & -7.2 & -26.9 & -38.3 & -38.7 \\
\hline $\begin{array}{l}\text { Plant and machine operators, and } \\
\text { assemblers }\end{array}$ & -18.5 & -40.2 & -29.8 & -25.6 & -43.6 & 25.3 & -50.2 \\
\hline Elementary occupations & -9.2 & 12.2 & -19.2 & 7.5 & -35.0 & -41.8 & -21.5 \\
\hline
\end{tabular}

Source: ILO, Employment by economic activity and occupation database

Actually, we suggest changing perspective and viewing this restructuring of industry as an effective reshaping of economic space in Europe. There are no more clearly-defined national economic systems but an entire integrating region in an uncertainly-defined political space. Such a process of unification tends to reinforce high value added activities in the polycentric space situated in the Paris- 
Amsterdam-Berlin-Frankfurt quadrangle. Lower value-added activities are moving to the periphery which, in order to retain its financial viability is obliged to keep its labour costs low.

This view is reinforced by the peculiar case of Italy, which was the most developed of the Southern economies. In fact, core European companies have purchased many leading industries in the South, although it is also the case that Italian companies in public utilities that expanded abroad. A significant part of the Italian fashion trademarks has been bought up by French firms ${ }^{4}$. French capitalism, which with Germany already was dominant in large-scale retail trade, has also gone on an intensive shopping spree in services such as telecommunications, public utilities and in finance: between 2012 and 2017, French companies announced $\$ 41.8$ in Italian takeovers - triggering something of a nationalist backlash from Italian financiers and industrialists (Mawad et al 2017). However, while these acquisitions could be a simple effect of economic integration (and of Italian financial disarray - small and medium-sized Italian firms find it difficult to access the capital require for consolidation in Italy), what is really highlighting the 'peripheralization effect' is the trend for successful Italian companies to move their headquarters to the European 'core': FCA (Fiat Chrysler Automobiles) has moved its administrative headquarters from Turin to Amsterdam (its fiscal residence is London), while the Italian Luxottica (one of the largest eyewear companies in the world with sales for 9,15 billions of euros and net profits for 970 million of euros $)^{5}$ is merging with Essilor and moving its headquarters to Paris - just one more example of the tendency to centralize managerial activities in Europe.

This situation poses a problem of cohesion and eventually of identity and hence a big uncertainty in the policies to be enacted to achieve an external equilibrium between the different regions. Sometimes, a solution is to concentrate all economic activities in the central regions and let the periphery specialize in tourism and agriculture. This was, for instance, the case of French peripheral regions. Yet this solution would be harder to implement at the European level as entire countries are concerned. Anyway, this is the natural restructuring direction taken by many regions in the South, where former national centres (Milan, Lisbon, Athens, Madrid) are losing ground compared to continental ones, becoming less important 'second order' centres.

\footnotetext{
${ }^{4}$ Louis Vuitton Moët Hennessy (LVMH), the French luxury-goods group, owns Fendi, Cova, Loro Piana, Berluti and Bulgari, while Bottega Veneta and Gucci are owned by rival French company Kering, formerly Pinault-Printemps-Redoute. Georgio Armaniis controlled by the French L'Oréal Group. Other large Italian fashion companies - such as Tod's owned by Diego Della Valle (who is a core shareholder in Saks, the US luxury department store) have globalized themselves

${ }^{5}$ Luxottica owns many top brands like Ray-Ban, Oakley, Persol, Oliver Peoples, Alain Mikli, Arnette, Vogue Eyewear and many else.
} 
Table 6. Impact of the Crisis on Industrial Specialization Calculated by Employment - Eurostat

\begin{tabular}{|c|c|c|c|c|c|c|c|c|c|c|c|c|}
\hline 2008-2012 & Germ & any & Gre & & Spa & & Fra & & Ita & & Portı & gal \\
\hline NACE_R2/GEO & $\begin{array}{c}\text { Var } \\
2012 / 2008\end{array}$ & $\begin{array}{c}\text { share in } \\
\text { total } \\
\text { change }\end{array}$ & $\begin{array}{c}\text { Var } \\
2012 / 2008\end{array}$ & $\begin{array}{l}\text { share in } \\
\text { total } \\
\text { change }\end{array}$ & $\begin{array}{c}\text { Var } \\
2012 / 2008\end{array}$ & $\begin{array}{l}\text { share in } \\
\text { total } \\
\text { change }\end{array}$ & $\begin{array}{c}\text { Var } \\
2012 / 2008\end{array}$ & $\begin{array}{l}\text { share in } \\
\text { total } \\
\text { change }\end{array}$ & $\begin{array}{c}\text { Var } \\
2012 / 2008\end{array}$ & $\begin{array}{c}\text { share in } \\
\text { total } \\
\text { change }\end{array}$ & $\begin{array}{c}\text { Var } \\
2012 / 2008\end{array}$ & $\begin{array}{c}\text { share in } \\
\text { total } \\
\text { change }\end{array}$ \\
\hline Manufacturing & $0.8 \%$ & $100.0 \%$ & $-16.8 \%$ & $100.0 \%$ & $-25.1 \%$ & $100.0 \%$ & $-4.8 \%$ & $100.0 \%$ & $-11.6 \%$ & $100.0 \%$ & $-16.9 \%$ & $100.0 \%$ \\
\hline $\begin{array}{l}\text { Manufacture of food } \\
\text { products }\end{array}$ & $5.5 \%$ & $71.4 \%$ & $7.0 \%$ & $-8.4 \%$ & $-6.9 \%$ & $3.9 \%$ & $11.7 \%$ & $-37.6 \%$ & $3.4 \%$ & $-2.4 \%$ & $-8.0 \%$ & $6.0 \%$ \\
\hline $\begin{array}{l}\text { Manufacture of } \\
\text { beverages }\end{array}$ & $-6.5 \%$ & $-8.4 \%$ & $-2.2 \%$ & $0.4 \%$ & $-9.8 \%$ & $0.9 \%$ & - & & - & & $-5.3 \%$ & $0.6 \%$ \\
\hline $\begin{array}{l}\text { Manufacture of } \\
\text { tobacco products }\end{array}$ & $0.4 \%$ & $0.1 \%$ & $-32.7 \%$ & $1.4 \%$ & $-21.5 \%$ & $0.1 \%$ & - & & - & & - & \\
\hline $\begin{array}{l}\text { Manufacture of } \\
\text { textiles }\end{array}$ & $-10.8 \%$ & $-16.2 \%$ & $-39.7 \%$ & $9.6 \%$ & $-33.5 \%$ & $3.2 \%$ & $-24.2 \%$ & $8.8 \%$ & $-22.8 \%$ & $7.9 \%$ & $-27.7 \%$ & $11.7 \%$ \\
\hline $\begin{array}{l}\text { Manufacture of } \\
\text { wearing apparel }\end{array}$ & $-13.2 \%$ & $-11.2 \%$ & $-27.3 \%$ & $9.8 \%$ & $-44.6 \%$ & $5.9 \%$ & $-25.8 \%$ & $9.6 \%$ & $-17.2 \%$ & $8.6 \%$ & $-26.1 \%$ & $22.3 \%$ \\
\hline $\begin{array}{l}\text { Manufacture of } \\
\text { leather and related } \\
\text { products }\end{array}$ & $-6.0 \%$ & $-1.9 \%$ & $-46.9 \%$ & $2.7 \%$ & $-24.1 \%$ & $1.7 \%$ & $3.1 \%$ & $-0.5 \%$ & $-6.8 \%$ & $2.0 \%$ & $0.5 \%$ & $-0.2 \%$ \\
\hline $\begin{array}{l}\text { Manufacture of } \\
\text { wood products }\end{array}$ & $-1.8 \%$ & $-3.9 \%$ & $-6.5 \%$ & $0.8 \%$ & $-41.6 \%$ & $5.8 \%$ & $4.4 \%$ & $-1.8 \%$ & $-17.1 \%$ & $4.1 \%$ & $-25.5 \%$ & $7.4 \%$ \\
\hline $\begin{array}{l}\text { Manufacture of } \\
\text { paper and paper } \\
\text { products }\end{array}$ & $0.2 \%$ & $0.6 \%$ & $-15.7 \%$ & $2.4 \%$ & $-15.9 \%$ & $1.5 \%$ & $-5.3 \%$ & $2.5 \%$ & $-3.7 \%$ & $0.6 \%$ & $-9.8 \%$ & $0.9 \%$ \\
\hline $\begin{array}{l}\text { Printing and } \\
\text { reproduction of } \\
\text { recorded media }\end{array}$ & $-9.5 \%$ & $-28.0 \%$ & $-9.9 \%$ & $1.7 \%$ & $-29.6 \%$ & $4.2 \%$ & $-21.3 \%$ & $11.7 \%$ & $-18.6 \%$ & $3.6 \%$ & $-25.4 \%$ & $4.2 \%$ \\
\hline $\begin{array}{l}\text { Manufacture of coke } \\
\text { and refined } \\
\text { petroleum }\end{array}$ & $-2.6 \%$ & $-0.9 \%$ & $-14.2 \%$ & $1.2 \%$ & $4.3 \%$ & $-0.1 \%$ & - & & $-1.5 \%$ & $0.1 \%$ & - & \\
\hline $\begin{array}{l}\text { Manufacture of } \\
\text { chemicals and } \\
\text { chemicals }\end{array}$ & $2.5 \%$ & $14.5 \%$ & $-17.2 \%$ & $4.1 \%$ & $-13.6 \%$ & $2.2 \%$ & $-4.2 \%$ & $4.4 \%$ & $-6.2 \%$ & $1.6 \%$ & $-14.9 \%$ & $1.7 \%$ \\
\hline $\begin{array}{l}\text { Manufacture of } \\
\text { pharmaceuticals }\end{array}$ & $-3.4 \%$ & $-7.5 \%$ & $0.9 \%$ & $-0.1 \%$ & $-9.0 \%$ & $0.6 \%$ & $-9.5 \%$ & $5.4 \%$ & $-9.0 \%$ & $1.4 \%$ & $-1.9 \%$ & $0.1 \%$ \\
\hline
\end{tabular}




\begin{tabular}{|c|c|c|c|c|c|c|c|c|c|c|c|c|}
\hline $\begin{array}{l}\text { Manufacture of } \\
\text { rubber and plastic } \\
\text { products }\end{array}$ & $2.9 \%$ & $19.8 \%$ & $-11.1 \%$ & $2.9 \%$ & $-22.9 \%$ & $4.6 \%$ & $-20.8 \%$ & $29.0 \%$ & $-7.2 \%$ & $3.0 \%$ & $-5.1 \%$ & $1.0 \%$ \\
\hline $\begin{array}{l}\text { Manufacture of } \\
\text { other non-metallic } \\
\text { minerals }\end{array}$ & $-0.3 \%$ & $-1.3 \%$ & $-31.0 \%$ & $13.2 \%$ & $-44.7 \%$ & $13.9 \%$ & $-10.2 \%$ & $8.7 \%$ & $-21.4 \%$ & $10.3 \%$ & $-25.9 \%$ & $11.0 \%$ \\
\hline $\begin{array}{l}\text { Manufacture of } \\
\text { basic metals }\end{array}$ & $-3.6 \%$ & $-17.2 \%$ & $-13.0 \%$ & $4.4 \%$ & $-20.6 \%$ & $2.7 \%$ & $-21.8 \%$ & $15.0 \%$ & $-11.1 \%$ & $3.4 \%$ & $-18.5 \%$ & $1.5 \%$ \\
\hline $\begin{array}{l}\text { Manufacture of } \\
\text { fabricated metal } \\
\text { products }\end{array}$ & $1.4 \%$ & $20.1 \%$ & $-27.4 \%$ & $18.1 \%$ & $-36.9 \%$ & $22.0 \%$ & $-2.5 \%$ & $5.4 \%$ & $-17.4 \%$ & $21.4 \%$ & $-15.4 \%$ & $10.7 \%$ \\
\hline $\begin{array}{l}\text { Manufacture of } \\
\text { computer. electronic } \\
\text { and optics }\end{array}$ & $-2.8 \%$ & $-15.6 \%$ & $-39.6 \%$ & $3.4 \%$ & $-30.8 \%$ & $2.1 \%$ & $-6.3 \%$ & $6.4 \%$ & $-13.2 \%$ & $3.6 \%$ & $-13.1 \%$ & $1.0 \%$ \\
\hline $\begin{array}{l}\text { Manufacture of } \\
\text { electrical equipment }\end{array}$ & $1.8 \%$ & $15.4 \%$ & $-16.9 \%$ & $2.7 \%$ & $-24.9 \%$ & $3.6 \%$ & $-15.0 \%$ & $13.8 \%$ & $-10.3 \%$ & $4.1 \%$ & $-7.3 \%$ & $1.1 \%$ \\
\hline $\begin{array}{l}\text { Manufacture of } \\
\text { machinery and } \\
\text { equipment n.e.c. }\end{array}$ & $-1.5 \%$ & $-28.2 \%$ & $-26.6 \%$ & $8.2 \%$ & $-24.4 \%$ & $5.5 \%$ & $-16.0 \%$ & $22.8 \%$ & $-5.8 \%$ & $6.0 \%$ & $-17.2 \%$ & $3.4 \%$ \\
\hline $\begin{array}{l}\text { Manufacture of } \\
\text { motor vehicles. } \\
\text { trailers }\end{array}$ & $1.8 \%$ & $25.6 \%$ & $-34.8 \%$ & $2.7 \%$ & $-18.0 \%$ & $5.1 \%$ & $-6.2 \%$ & $10.8 \%$ & $-11.1 \%$ & $4.6 \%$ & $-17.2 \%$ & $5.0 \%$ \\
\hline $\begin{array}{l}\text { Manufacture of } \\
\text { other transport } \\
\text { equipment }\end{array}$ & $3.9 \%$ & $7.9 \%$ & $-41.1 \%$ & $5.6 \%$ & $-11.2 \%$ & $1.0 \%$ & $1.6 \%$ & $-1.4 \%$ & $-15.2 \%$ & $3.4 \%$ & $-52.5 \%$ & $3.5 \%$ \\
\hline $\begin{array}{l}\text { Manufacture of } \\
\text { furniture }\end{array}$ & $-8.4 \%$ & $-21.2 \%$ & $-28.5 \%$ & $6.8 \%$ & $-45.6 \%$ & $8.3 \%$ & $-15.8 \%$ & $6.1 \%$ & $-21.4 \%$ & $7.5 \%$ & $-23.6 \%$ & $6.8 \%$ \\
\hline Other manufacturing & $8.8 \%$ & $33.6 \%$ & $-27.0 \%$ & $3.3 \%$ & $-15.1 \%$ & $1.0 \%$ & $-1.7 \%$ & $0.8 \%$ & $-15.3 \%$ & $3.4 \%$ & $-10.0 \%$ & $1.0 \%$ \\
\hline $\begin{array}{l}\text { Repair and } \\
\text { installation of } \\
\text { machinery and } \\
\text { equip. } \\
\end{array}$ & $15.8 \%$ & $52.6 \%$ & $-17.1 \%$ & $3.0 \%$ & $-3.9 \%$ & $0.4 \%$ & $9.8 \%$ & $-11.4 \%$ & $-4.3 \%$ & $1.2 \%$ & $6.9 \%$ & $-0.8 \%$ \\
\hline
\end{tabular}




\section{Conclusion: Managing a Polarized Space}

There is good news and bad news. The good news is that Europe is integrating economically as was hoped. The bad news is that this integration is not homogeneous and profitable for all, as many had expected (Eichengreen 1993, De Grauwe 1995, Krugman 1992). This uneven process is producing huge restructuring costs in the periphery without hopes for a reasonable medium-to-long term improvement of its economic systems and living standards. Southern European countries have prematurely abandoned industrial policy. On the other hand, the European Union still has no common political space for governing industrial change with coordinated policies and is suffering from a resurgence of industrial nationalism.

The centralization of the European economy was predicted by many economists in the 1990s (Bayoumi and Eichengreen 1993, Feldstein 1997). The story was that increasing returns to scale and trade would encourage firms to locate close to large markets, or firms would locate in core markets, so they could enjoy positive externalities such as lower demand uncertainty and experience steadier growth than in the periphery. These factors favor, therefore, the agglomeration of economic activities. Rising factor prices also induce migration, thereby furthering the agglomeration effects instead of balancing productivity levels. In fact, centralization is occurring in more complex ways than expected. It is not much a problem of declining competitiveness of peripheral firms as the fact that financial and managerial activities tend to move to the centre and peripheral production activities become subordinate to the former, exposed to tough competition and enjoying low profit margins.

Unexpectedly, finance has also contributed to this process of weakening the Southern economies. What until 2007 was a solid advantage of Southern Europe the credit-based financial system - became a source of weakness within Banking Union where credit has been defined as the riskier activity in banks' assets and one subject to tough control by the authorities. That has contributed to a further decline of industry due to the drying-up of credit for many firms.

European free trade policy was conceived to help develop an open commercial space. However, the EU economic space is naturally polarized and the removal of institutional barriers to the movement of production factors tends to help the shift of high-value activity to the European core. This may indeed be a source of increased productivity, but it also produces high social costs in the periphery (Reinert 2013, Reinert and Kattel 2004). In our analysis, it does not only produce deindustrialization but a peripheralization of production activities. Therefore, the centre-periphery problem is a critical issue to be tackled now by European policies (Aiginger 2014).

The example of downsizing the food industry in the Iberian regions and its growth in France and Germany is relevant here. Continental regions are not expected to enjoy any real comparative advantage in producing food (with some exceptions), but apparently they do have an advantage in managing such activities. The actual situation is that the ownership and management of these industries is, as in fashion and transport equipment, moving steadily towards the central regions of 
Europe, while peripheral regions are left with lower-value production activities, under the constant threat of relocation elsewhere. The analysis of comparative advantages in managerial activities would open up new and unexplored fields of research in political economy.

The real alternative that Europe faces now is therefore between developing a stronger coordination between centre and periphery, which means inducing a different and complementary form of specialisation of the different European regions through a certain amount of 'planning' (in other words, sacrificing some external free trade and introducing coordinated income policies at the European level); and allowing for a greater degree of policy autonomy for peripheral countries to pursue industrial policies, even if they conflict with European free competition policies.

If Europe's economic space is polarized, any general industrial policy would not benefit greatly the periphery. The latter option means allowing further European economic integration, triggering defensive nationalistic public expenditure, with unforeseeable consequences. The former option would imply a coordinated strategy of development between central regions and peripheral areas (Wade 2012), but there is no political consent for this option. Above all, this coordination would have to define what peripheral areas should specialize in. If no specific decision on European industrial policy is taken, the risk is that the European periphery will lose valuable activities. The only variable left to maintain economic balances would be to continue reducing the cost of labour, leading to a progressively impoverished economy.

\section{Bibliography}

Amable B (2003) The Diversity of Modern Capitalism. Oxford: Oxford University Press.

Aiginger K (2014) 'Industrial Policy for a Sustainable Growth Path', WIFO working paper no.469. Available at https://ideas.repec.org/p/wfo/wpaper/y2014i469.html.

Arrighi G, Drangel J (1986) 'The Stratification of the World Economy: An Exploration of the Semiperipheral Zone'. Review (Fernand Braudel Center) 10(1): 9-74.

Arrighi G, Piselli F (1987) 'Capitalist Development in Hostile Environments: Feuds, Class Struggles, and Migrations in a Peripheral Region of Southern Italy'. Review (Fernand Braudel Center) 10(4): 649-751.

Bayoumi T, Eichengreen B (1993) Shocking Aspects of European Monetary Uification, in Adjustment and Growth in the European Monetary Union, Fransisco Torres and Francesco Giavazzi (eds). Cambridge: Cambridge University Press.

Baumeister M, Sala R (2015) Southern Europe?: Italy, Spain, Portugal, and Greece from the 1950s until the present day, Frankfurt, Campus Verlag.

Barradas R, Lagoa S, Leao E, Paes Mamede R (2018) 'Financialization in the European Periphery and the Sovereign Debt Crisis: The Portuguese Case'. Journal of Economic Issues LII (4): 1056-1083.

Becker J (2013) 'The Periphery in the Present International Crisis: Uneven Development, Uneven Impact and Different Responses'. Spectrum: Journal of Global Studies 5(1): 21-41. 
Becker J, Jäger J (2012) 'Integration in Crisis: A Regulationist Perspective on the Interaction of European Varieties of Capitalism'. Competition and Change 16(3): 169187.

Becker J, Johannes J, Leubolt B, Weissenbacher R (2010) 'Peripheral Financialisation and Vulnerability to Crisis: A Regulationist Perspective'. Competition and Change 14( 34): 225-247.

Camagni R (2001) 'On the Concept of Territorial Competitiveness: Sound or Misleading?'. Urban Studies 39(13): 2395-2411.

Celi G, Ginzburg A, Guariscio D, Simonazzi A (2017) Crisis in the European Monetary Union. A Core-Periphery Perspective. Abingdon: Routledge.

De Grauwe P (1995) Alternative Strategies towards Monetary Union. European Economic Review 39(3): 483-491.

Eichengreen B (1993) European Monetary Unification. Journal of Economic Literature XXXI: 1321-1357.

Epstein R (2014) 'Overcoming Economic 'Backwardness' in the European Union'. Journal of Common Market Studies 52(1): 17-34.

Feldstein M (1997) EMU and International Conflict. Foreign Affairs 76(6): 60-73.

Ferrera M, Rhodes M (eds) (2000) 'Recasting European Welfare States'. Special Issue of West European Politics 23(2).

Fischer-Tahir A, Naumann M (2013) 'Peripheralization as the Social Production of Spatial Dependencies and Injustice', in A. Fischer-Tahir and M. Naumann (eds) Peripheralization, pp. 9-26. Wiesebaden: Springer.

Gambarotto F, Solari S (2009) Regional Dispersion of Economic Activities and Models of Capitalism in Europe. Economie Appliquée LXI(1): 5-38.

Gambarotto F, Solari S (2015) 'The Peripheralization of Southern European Capitalism within the EMU'. Review of International Political Economy 22(4): 788-812.

Hall PA (2014) 'Varieties of Capitalism and the Euro Crisis'. West European Politics 37(6): 1223-43.

Hall PA, Soskice D (2001) 'An Introduction to Varieties of Capitalism', in PA Hall, D Soskice (eds), Varieties of Capitalism: The Institutional Foundations of Comparative Advantage, pp. 1-68. Oxford: Oxford University Press.

Hopkin JR (2015) 'The Troubled South: The Euro Crisis in Italy and Spain' in M Blyth, M Matthijs (eds.) the Future of the Euro. Oxford: Oxford University Press.

Jäger J, Springler E (2015) Asymmetric Crisis in Europe and Possible Futures Critical Political Economy and Post-Keynesian Perspectives. Abingdon: Routledge.

Koutsoukis N-S, Roukanas S (2016) 'Compulsory' Economic Deflation turned Political Risk: Effects of Austere Decision- making on Greece's 'True' Economy (2008-2015) and the 'Eurozone or Default' Dilemma" in A Karasavvoglou, D Kyrkilis, G Makris, P Polychronidou (eds) Economic Crisis, Development and Competitiveness in Southeastern Europe Theoretical Foundations and Policy Issues. pp 41-56. Switzerland: Springer.

Krugman P (1992) Policy Problems of a Monetary Union. In Currencies and Crises. Cambridge, MA: MIT Press.

Lains P (2019) 'Convergence, Divergence, and Policy: Portugal in the European Union', in West European Politics forthcoming.

Magone JM (2016) 'From 'Superficial' to 'Coercive' Europeanization in Southern Europe: The Lack of Ownership of National Reforms' in JM Magone. B laffan, C Schweiger (eds) Core-Periphery Relations in the European Union, pp. 87-98. London: Routledge.

Magone JM, Laffan B, Schweiger C (2016) 'The European Union as a Dualist Political Economy: Understanding Core-periphery Relations' in JM Magone, B Laffan, C 
Schweiger (eds) Core-Periphery Relations in the European Union, pp. 1-16. London: Routledge.

Mawad M, Boksenbaum-Granier A, Follain J (2017) 'The Plan to Stop French Raiders Buying Up Italian Businesses' Bloomberg Markets, 7 February. Available at https:// www.bloomberg.com/news/articles/2017-02-08/france-inc-s-italian-binge-raises-road blocks-from-milan-to-rome.

Nölke A (2016) 'Economic causes of the Eurozone Crisis: The Analytical Contribution of Comparative Capitalism'. Socio-Economic Review 14(1): 141-161.

Orsi L, Solari S (2010) 'Financialisation in Southern European Countries'. Economie Appliquée LXIII(4): 5-34.

Molina O, Rhodes M (2007) 'The Political Economy of Adjustment in Mixed Market Economies: A Study of Spain and Italy" in B. Hancké, M. Rhodes and M. Thatcher (eds.) Beyond Varieties of Capitalism: Conflict, Contradiction and Complementarities in the European Economy, pp. 223-252. Oxford: Oxford University Press.

Rangone M, Solari S (2012) "Southern European' Capitalism and the Social Costs of Business Enterprise', Studi e Note di Economia XVI(1): 3-28.

Reinert E (2013) 'Primitivization of the EU Periphery: The Loss of Relevant Knowledge', IzR. - Informationen zur Raumentwicklung/Information on Spatial Development, Bonn, Germany, Bundesinstitut für Bau-, Stadt- und Raumforschung (BBSR), No 1.

Reinert E, Kattel R (2004) 'The Qualitative Shift in European Integration: Towards Permanent Wage Pressures and a 'Latin-Americanization' of Europe?, PRAXIS working paper no. 17. Available at: http://mpra.ub.uni- muenchen.de/47909/1/MP RA_paper_47909.pdf.

Simonazzi A, Ginzburg A, Nocella G (2013) 'Economic Relations between Germany and Southern Europe'. Cambridge Journal of Economics 37(3): 653-675.

Stockhammer E (2008) 'Financialisation and the Slowdown of Accumulation'. Cambridge Journal of Economics 28(5): 719-41.

Stockhammer E (2011) 'Peripheral Europe's Debt and German Wages'. International Journal of Public Policy 7: 83-96.

van der Zwan N (2014) Making Sense of Financialization. Socio-Economic Review 12(1): 99-129.

Wade R H (2012) 'Return of Industrial Policy?' International Review of Applied Economics 26(2): 223-239.

Wallerstein, I. (1979). The Capitalist World Economy. New York: Cambridge University Press. 
